\title{
Automation and Digitization of Primary/Post Primary School Libraries as an Impetus for Effective Teaching and Learning
}

Suleiman Bello

\author{
Federal College of Education, P.M.B. 1041, Zaria,
}

Kaduna State, Nigeria

\section{Doi:10.5901/jesr.2013.v3n10p79}

\begin{abstract}
This paper focuses on Automation and Digitization of school libraries as an impetus for effective teaching and learning. This is to facilitate information searches and retrieval with the use of computer hardware's and software's necessary for this action. The paper also discusses school libraries with its sole objective of improving teaching and learning in primary and post primary schools by providing necessary materials that will complement and supplement school curriculum. The resources and services available in school libraries such as, print and non-print were also enumerated. The paper also highlighted the concept of digitization Automation as it enhances effective use of library resources. Challenges encountered in Digitizing school libraries as inadequate funding, lack of qualified manpower to operate the computer system, inadequate facilities and equipment e.t.c. were also emphasized. Conclusively, the paper proffers recommendations as a way forward to the challenges encountered in school libraries.
\end{abstract}

Keywords: Automation, Digitization, School Libraries, Teaching and Learning

\section{Introduction}

The impact of effective library services to the achievements of the academic aspirations of institution cannot be over stressed. Undoubted quick access to relevant information has been considered one of the crucial factors for success in any man's numerous activities. For instance in modern society no wise man would take any socio-economic matter without adequate supply of relevant information. Similarly, it has also been realized that in fields of human activities, there are jobs and duties requiring speed and accuracy for their performances. A library service is one of such human activities. Hence the new manifestation of interest for computer by librarian in Nigeria with desire for promoting effective library service across the country (Abdullah, 2002).

It has also been observed that at the international level, information has become an unprecedented crucial factor in the race for who rules the world. It is little wonder then that countries like United State of America invest abundant resources in the storage and dissemination of information in the firm believes that he who runs the information runs the show.

Chan (2002) argued that to consider survival without information is to think of surviving without food, water and protection. Knowing who your enemies are, where they are, their numbers and weapons are basic to survival. Modern intelligence systems and the application of computers are based on discovering and accessing this information in much sophisticated way than our ancestors. It is valueless to find out after the battle even if, it helps you to justify why you lost.

In a recent survey study conducted, the Education Sector Analysis (ESA) of the Federal Ministry of Education, the following information is known concerning the state of school library services in Nigeria schools. There were libraries in some primary and secondary schools providing some form of services to support teaching and learning in the schools. The learning resources collections consist mainly of books reference, fiction and non-fiction. The services also include 
provision of materials to support the curriculum and to promote reading.

The school library provides not only varied resources for learning but also be a conducive environment. The library setting encourages self-directed learning, as students conduct independent searches for information, utilizing available resources or survey other possible sources. The library environment fosters cooperation and group work, as students work together on project (Cohn, Kelsey \& Fiels, 1997). In addition to this the school library also provides services such as:

a. Teaching the skills of using an appreciating book

b. Developing interest in reading through story hour, book talks and group activities

c. Creating awareness for library collection through displays and preparation of book list

d. Working with teachers to plan class assignment and project that will require the use of library resources to complete the assignment

e. Encouraging the use of skills in design, creative writing, production and use of instructional media to teachers and pupils

f. Creating a circulate system that will facilitate the effective use of learning resources in the school library

g. Production of instructional materials

How we care for our collection is the natural reflection of the value we place in them. For some time, our preservation efforts have been static and dependable: binding for journals, binding for paper back monographs, regular repair of heavily - used items, specialized repair for valuable items and decent environmental conditions have formed the standard. Predictably, as collections are changing so is the issues attendant to preservation. Perhaps the biggest dynamic is the change in scholarly publishing, fueling the discussion over what preservation is and should be in an increasingly digital world. At present, preservation librarians point out that a digital surrogate to an item in print item through less handing, but it does not provide the long term protection to which school libraries generally aspire. Thus the use of acid-neutral paper and microform continue to provide the best preservation available to school libraries.

A computer is a fast and accurate electronic device that has the ability to automatically accept data, process data and produce results under the influence or direction of stored program of instructions. According to IFLA/UNESCO (2000), a computer is a "machine which will accept data and series of sequenced instructions and which will then process by data according to the instruction by a human being". Gbaje (2007) sees the computer as nothing more than a glorified calculation. It has no intelligence of its own, and only does what you tell it to do, for a computer to be meaningfully used; the librarian or the operator must learn to speak the computer how to do a job.

The term automation refers to a wide variety of systems and processes that operate with little or no human intervention. In the most modern automation systems, control is exercised by the system itself, through control devices that sense changes in such conditions as temperature, rate of flow, and volume and then command the system to make adjustments to compensate for these changes. The applications of automation are widespread indeed; most modern industrial operations are too complex to be handled manually, or even with simple machines under manual control.

Digitization refers to all of the steps involved in the process of making collections of materials available online. This includes selection of collection/materials based on the collection development policy of the institutions, scanning material, transcribing, creating mark up and index, creating metadata, quality control by subject specialist, processing images, uploading to the web, preservation and maintaining archival media and online collections. (Gbaje, 2007). Similarly, Kasbon (2001) said digitization involves the process of making none digitally borne materials available into digital format. The retrospective conversion of printed library cards into Machine Readable Catalogue (MARC) represents one of the earliest digitization processes. Digitization process includes selection collection/materials, as soon as selection is made scanning of the materials selected follows. And then transcribing and creating mark up and index, creating metadata quality control by subject specialist, processing images, populating the appropriate digital 
assert management software (DAMS), Digital assert management software such as Dspace, Fefora, Greenstone collect, index and provide queries over a catalogue of meta - data records accessible locally and remotely. The advantage of Digital library includes:

It allows one copying of information resources to their user's desired destinations, diskette, $C D$, or stored in the users' personal computer.

- Electronic information resources can be sorted, transmitted and retrieved easily and quickly.

\section{Primary/Post-Primary School Libraries}

The library is one of the busiest and most important parts of a school. The purpose of primary or elementary school libraries is to provide materials to supports the school curriculum and to promote reading. It has three basic jobs in helping children learn. First, it provides books and other materials for the school's educational program, carefully fitting them in with the needs of the children. Second, it helps the children develop an interest in many subjects. Third, it teaches how to use a library (Khalid, 1997).

Cohn, Kelsey \& Fiels, (1997) views the school library as the heart of the school around which the school programme revolves. This perception makes the school library look like an entity, an institution in its own right that offers library services to students, teachers, and members of the school community and friends of the library.

Fatimah (2002) observes the school library as a media centre, a learning laboratory and resource centre where school children are entrusted to a specialist who directs learning activities to their benefit. Other schools also share this view.

Early school libraries concentrated on enriching textbook teaching with supplementary materials and introducing children to the wonderful world of imaginative literature, reforms precipitated by the extraordinary increase in knowledge, proliferation of communication technologies, and findings of educational research. School libraries emerged as the places where students or pupils would learn from a range of information sources and media, using "discovery" and problem - solving learning procedures.

In 1945, the American Library Association published postural standards, school libraries for Today and Tomorrow, which defined the educational purposes of the school library as follows:

$\checkmark$ Participate effectively in the school program as it strives to meet the needs of pupils, teachers, parents, and other community members.

$\checkmark$ Provides boys and girls with the library materials and services most appropriate and most meaningful in their growth and development as individuals.

$\checkmark$ Stimulate and guide pupils in all phases of their reading so that they may find increasing enjoyment and appreciation.

$\checkmark$ Provide an opportunity through library experiences for boys and girls to develop helpful interests, to make satisfactory personal adjustments, and to acquire desirable social attitudes.

$\checkmark$ Help children and young people to become skillful and discriminating users of libraries and printed and audio - visual materials.

$\checkmark$ Introduce pupils to community libraries as early as possible and cooperate with those libraries in their efforts to encourage combining education and cultural growth.

$\checkmark$ Work with teachers in the selection and use of all types of library materials which contribute to the teaching program.

$\checkmark$ Participate with teachers and administrators in programs for continuing professional and cultural growth of the school staff.

$\checkmark$ Cooperate with other libraries and community leaders in planning and developing an over - all library programs for the community or area. 


\section{Library Automation}

Khalid (1997) defines automation as a process in which mechanical or electronic devices are employed to carry out tasks without human intervention. Fatimah (2002) however, defined library automatic and semi-automatic data processing machines to perform such traditional library activities as acquisitions, cataloguing and circulation.

The rise of computer development can be traced to Hermon Hollireth who invented to punch card. An idea he borrowed from John Shaw Billings, the Director of the Surgeon - General library (now the National Library of Medicine), and Dictionary of American Biography (1964).

Automating a library can be divided into 3 different types:

I. Word Processing Automation

II. Spread Sheet Automation

III. Data Management Automation

\section{Word Processing Automation}

Word processing is the process of moving text or information from the originator to paper through an electronic device. The word processor store text, sorts them, print them and even process the text. There are stands - alone word processor that perform the world processing tasks alone. In recent times, most of word processing in the libraries is done with the help of computer word processing software like Microsoft words, word perfect, word star, page maker, print master, etc. According Meckler (2001), when a library starts using computer as word processor to type, store, retrieve and print documents that library is considered to be partially automated.

Meckler (2001) further classified the word processing tasks in libraries into the following groups:

$\checkmark$ Production of common library documents, such as library newsletters, library management reports, new book list, special bibliographies, etc;

$\checkmark$ Production of overdue book notices;

$\checkmark$ Production of statistical reports;

$\checkmark$ Use of optical scanner to read data from sources, this is especially if you find yourself rekeeping from documents and use of an optical scanner to scan pictures, groups, images etc

$\checkmark$ Managing text and hypertext;

$\checkmark$ Compilation of indexes and

$\checkmark$ Using CD-Room and printing information from them

\section{Spreadsheet Automation}

Spreadsheets are typically used to automate functions in libraries requiring manipulation of numbers. For many tasks, the spreadsheet table formats serves a useful purpose. The information is formatted as one goes along entering data to be processed for easy manipulation. The row and column format is usually an enough structure to give one a place to start. A spreadsheet can function as a small database with the advantage of easy calculations. Spreadsheet products have taken advantage of the popularity of spreadsheet programmes by adding word processing, printing and report 5 writing functions. Data management options are relatively sophisticated including selection and sorting. Some of the soft wares use in projects/this operation are Lotus 123, excel etc.

\section{Database Management System (DBMS) Automation}

A database is a collection of logical related files with minimum redundancy, organized in a manner 
to satisfy the information needs of an organization. In another dimension, Gbaje,(2007) defined a database as "group or records or a file of information in library, either automated or manual". The software developed specifically for managements of database are called Database Management System (DBMS).

Library management database management software like NLAS, XLIB, TINLIB etc. and the one developed for ZCS library are used in school libraries in the following areas:

1. Catalogue for general/special collections of printed information resources videos, music serial holdings, reference materials, computer software, etc.

2. Inventory or equipment

3. A list of pupils/students, such as mailing list

4. Vertical files or pamphlet index

\section{Process of Digitization}

Digitization involves the process of making none digitally borne materials available into digital format. The retrospective conversion of printed library cards into machine readable catalog (MARC) represents one of the earliest digitization processes. Digitization process includes selection collection/materials as soon selection is made scanning of the materials selected follows. And then transcribing and creating mark up and index, creating meta-data, quality control by subject specialist, processing images populating the appropriate digital assert management software (DAM), Digital Assert Software such as Dspace, Fefora, Greenstone collect, index and provide queries over a catalogue of meta-data records accessible locally and remotely.

\section{Advantages of Digitization}

1. While conventional library system allows the removal of the information resources from the shelves for use whenever later returned, the contemporary digital information system and services allows for the copying of information resources to the user's desired destinations, diskette, $C D$, or stored in the User's personal computer.

2. Apart from providing information resources, the digital information system and services also allows the users to perform and enjoy other services such as e-publishing, e-mail, ejournal, e-books, e-commerce etc.

3. Electronic information resources could also be linked and interactive with cheaper access.

4. The digital library could be seen as a two way system of information delivery and transfer.

5. The ideal library cooperation is much more realizable with Electronic Information Resources (EIR) typical examples of these trends are the applications of the internet and the World Wide Web (WWW) to electronic publishing and access to online information.

6. Digital information system and services reduce cost significantly especially in terms of building/extension of librarians, space, personal and redundancy of collection

7. Storage capacity: the amount of information that can be stored in a digital library cannot be realized in the manual system.

8. Speed computers (in digital library) are capable of executing millions of instructions per second. Calculations and comparisons that would normally take several days of human labor could be done in an hour by the computer. This means that, it gives timely information.

9. Accuracy: as computer are strictly on instructions and data, all information in or given by the computer is correct and the data are the result of processing will ever be accurate.

10. Security: There is high level of security in the digital information system and services. This is because computer software has facilities for password and other controls that reduces or eliminates case of insecurity to the computer system and data bases (MOE, 2001). 


\section{Application of Automation in School Libraries}

School library automation is the application of information technologies to library operations and services, Zainab \& Abrizah (2002) identified the application in libraries in the following areas:

1. Ordering and acquisitions

2. Cataloguing

3. Circulation control

4. Serials control the Ordering process is particularly suited to computerization as it is a relatively simple clerical process, where similar operations are applicable to all categories of library (Zainab \& Abrizah, 2002).

The functions of an ordering or acquisitions systems are:

i. To receive records of information materials to be acquired

ii. Establish whether information materials required are already in stock or on order

iii. To print orders

iv. To check when orders are overdue and follow up overdue orders

v. To note the arrival of ordered information materials and prepare for payment

Some ordering systems also notify individuals the receipt or information materials, and produce a list of recently acquired information materials which will be placed on notice board. The details of the information material to be acquired need to be stated. That is the title of the information materials to be acquired need to be stated. That is the title of the information materials, ISBN/ISSN, name of author(s), number of copies ordered, publishers, vendors etc.

Cataloguing systems- computers are aids in producing catalogues most effectively and efficiently. This remain the reasons for computers being part of the cataloguing system is to create appropriate catalogues that can be drawn from any of the following sources.

$\checkmark$ A union files of the stock of several school libraries or other share database

$\checkmark$ The library's ordering or acquisition system

$\checkmark$ A file of records held by the school library

The advantages of computer base catalogue systems are:

i. The records in the catalogue database can be used not only in the catalogue subsystem, but also in order systems such as circulation control and acquisitions.

ii. Easy and effective interchange of catalogue records

iii. More effective interlibrary lending, cooperative acquisitions policies and cooperative storage ventures.

iv. No filing or other routine catalogue maintenance is required of cataloguers, except where it is necessary to alter stock records as the stock itself changes.

v. Different catalogues forms can be chosen for different catalogue locations

vi. Extract from the main catalogue database may be printed or consulted on line.

\section{Online Public Access Catalogue (OPAC)}

All library automated application systems offer online access to the catalogue or bibliographic database in some form or the other (Zainab \& Abrizah, 2002). Most systems offer both phrase and keyword searching with the phrase searching there is usually implicit right-hand truncation; for keyword searching, a truncation symbol is normally input if required.

After searching, once records are identified, there are number of ways in which they can be displayed. Some systems display the index or a listening of brief records before a full record is displayed; others, if there is only one match, will show the record directly. In addition to the online access to catalogues which can be used as a backup for security or at busy times, and which are useful in locations such as small branches. Hard copy can typically be produced the form of cards, printed catalogues, indexes and computer output on microform (CM). 


\section{Circulation Control Systems}

The application of computers-based library systems in circulation is in registration of library users, keeping track of movement of publications including charging. Discharging, renewal, and reservations of information materials. In addition, automated library circulation systems generates report of transactions by the user such as a list of publications at his/her possession, the data he/she I suppose to return them, and in the case of commercial libraries, any outstanding payment Raw Materials Research and Development Council (RMRDC, 2000:19).

The main purpose of computers based circulation system is to make library materials, including books and non-book materials to all users/patronizers immediately or as soon after the demand arises as in practicable. In other to achieve this, all school libraries must control circulation, by keeping records to specify.

i. Which information material is on loan

ii. What information material is in the library stock

iii. When material on loan will be available in the library for other users?

In addition to these basic functions, most school libraries also like their circulation control system to:

i. Recognize and possibly trap reserved books;

ii. Prepare overdue and recall notices;

iii. Facilities renewals

iv. Be reliable

v. Be economical

\section{Serial Control}

A serial, as defined by the International Serials Data System (ISDS), Paris is "a publication issued in successive parts and intended to be continued indefinitely' (Zainab \& Abrizah, 2002). Serials are distinguished from monographs by their ongoing nature. Serials control computer based system; usually have fewer titles to handle, but must record a greater number of transactions per title. Development of computerized serials control systems lagged behind similar systems for monographs. This slower progress was in part due to the essential complexity of a complete serials control system, but also derived from the lower priority associated with serials control as compared with monographs control. More development of serials-control systems has never been undertaken in academic and special libraries, where serials represent a larger proportion of the stock, than say in school libraries.

In Nigeria there are some indigenous computer base library systems like the X-lib, visual library, virtual library which have the capabilities of handling both monographs and serials.

\section{Problems Militating Against Automation and Digitization of School Libraries in Nigeria}

Nigeria school libraries are lacking behind in library automation and digitization as a result of certain factors which are both internal and external (Zainab \& Abrizah, 2002), Mohammed, technical, economical, sociological and political changes that have taken place in Nigeria. The first and most important according to them is finance. The adequate financial resources and the severe economic recession have made it prohibitive to purchase, operate and maintain new technologies needed for automation and digitization. A high rate of new technologies needed for automation and digitization. A high rate of inflation, low and unpredictable nation income, the effect of global economic depression and local currency devaluation continue to water down whatever budgetary provision is made for school libraries in Nigeria.

Any of the school libraries are not computer literate. This is a great setback in 
computerization. Many of the librarians are reluctant to jettison third old mindset which resists change. Many are conservative and traditional, and suffer computer phobia. Research result shows that, although the use of electronic information increases job satisfaction, confidence, and the effectiveness of librarians in their work, lack of technical expertise can be very frustrating to the librarians (Singh, 1996.). There is also lack of technical support. Only one librarian is formally trained to initiate, develop, implement and maintain computerized application in the entire school library system. Those who had been trained gain only limited, or no access, to the packages in which they had been trained. Inquisitive users with information technology (IT) skills cause serious dissatisfaction to the library staff (Khalid, 1997).

\section{Poor State of Power Generation}

Regular power generation remains a problem in Nigeria. Frequent power outages constitute a serious bottleneck to automation and digitization. The cost of running generating plant is prohibitive.

The lack of information technology skills and the view slow process of automation mean that the school library staff will take a very long time to become very familiar with the ALICE package, if the library staff find it difficult to get comfortable, the situation is worse for pupils or students, who depend so much on the school librarians for continuous orientation. Unfortunately, the library orientations programmed and the entire user education package do not fully address information technology skills.

\section{Poor Funding of School Library Service}

Poor funding is a major challenge to school library in Nigeria. School libraries in Nigeria mainly derive their funds from their parent authorities or organizations. A high rate of inflation, low and unpredictable nation income, the effect of global economic depression, and local currency devaluation continue to water down whatever budgetary provision is made for school libraries in Nigeria. Many school libraries in Nigeria have not initiated viable income generating strategies to supplement the parent organization funding.

\section{Education and Training}

Most staff in school libraries in Nigeria were trained in traditional librarianship. They are finding it difficult to cope with the requirements of the electronic age. Staff training and retraining have not been given a pride of place. The attitude is a great deterrent to the computerization of school library services.

The challenges have far reaching effects on the implementation and sustenance of the automation and digitization of school library service in Zaria Children's School.

\section{Recommendations}

1. Adequate funding should be provided to enhance effective teaching and learning.

2. Training and Retraining of school librarians should be emphasized and encouraged so as to enhance the productivity of school librarians in providing effective services to school library users.

3. Provision of necessary facilities and equipments for Automation and Digitization of School libraries.

4. Nigeria school libraries policies should be enacted, checked and evaluated.

5. There is the need for constant power supply to make effective use of facilities and equipments. 


\section{Conclusion}

School libraries are institutions, where books and other types of printed and non-printed information resources are housed in organized manner for the use of bonafide members only. Their functions are to serve the pupils and students, as information centers. School libraries have limited coverage of users, of same ages and educational backgrounds, which they have to cater for.

Automation is the process of employing mechanical or electronic devices to carry out tasks without human intervention, cataloguing, circulation and serials control. The state of art of automation in Nigerian school libraries is sympathetic.

Digitization involves the process of making non-digitally borne materials available in digital format. The retrospective conversion of printed library cards into machine- readable catalogue represents one of the earliest digitization process librarians have been involved with. According to Ezra (2007) digitization includes selection of collection/materials based on the collection development policy of the institutions, scanning materials, transcribing, creating mark up and index, creating metadata, quality control by subject specialist, processing images uploading to the web, preservation and maintaining archival media and online collection.

The problems militating against automation and digitization of school libraries in Nigeria are; Psychological, technical, economical, sociological and political changes that have taken place in Nigeria. The first and most important factor according to Fatimah (2002) and (Abdullah, 2002) is finance. The inadequate financial resources and the severe economic recession have made it prohibitive to purchase, operate, and maintain new technologies needed for automation and digitization.

According to Fatimah (2002), most of these computerized systems failed because of administrative bottle neck from the parent organizations, insufficient coordination, and breakdown of communication between the libraries and computer centers: another factor is the devaluation of naira, which resulted to escalating cost of information technologies. Lack of qualified computer staff in school libraries, and inconsistent power supply by the present power holding company of Nigeria (PHCN) "Former NEPA are also factors that contributed to the poor state of automation an digitization in Nigeria school libraries.

The present fuel intermittent and tax charges by the Nigerian government is another major factor that contributed to poor state of running automation and digitization in school libraries in Nigeria.

\section{References}

Abdullah, A. (2002). "Automating secondary school libraries: a web based library management system". In: Singh, Diljit et al (Eds.), School libraries for a knowledge society. Proceedings of the $31^{\text {st. IASL }}$ Annual Conference and $6^{\text {th }}$ International Forum on research in school librarianship, 5-9 August, at Petaling Jaya, Malaysia.

Ajibero, M.I (1985). "Library and the Community" in LISSA Journal (1)

Chan, F. M. (2002). "Development information literacy in the Malaysian smart schools: resource-based learning as a tool to prepare today's students for tomorrow's society". In: Singh, Diljit et al (Eds.), School libraries for a knowledge society. Paper presented at $31^{\text {st. }}$ IASL Annual Conference and $6^{\text {th }}$ International Forum on research in school librarianship, 5-9 August, at Petaling Jaya, Malaysia.

Cohn, J. M; Kelsey, A. L. and Fiels, K. M. (1997). Planning for automation- a how-to-do-it manual for librarians. New York: Neal-Schuman Publishers, Inc

Corbin, J. (1985). Managing the Library Automation Project, Arizona: the Oryx press, phoenix.

Dictionary of American biography, supplement one (1964/), Charles Scribes sons, New York.

Ezra, S.G. (2007). "Challenges of implementing virtual library for higher institutions in Nigeria", A Departmental Seminar Paper presentation (A.B.U) Zaria.

Fatimah, J. (2002). School libraries in Malaysia. In: Singh, D et al (Eds.), School libraries for a knowledge society, Proceedings of the $31^{\text {st. }}$ IASL Annual Conference and $6^{\text {th }}$ International Forum on research in 
school librarianship, 5-9 August, Petaling Jaya, Malaysia. Available at: http://www.iaslslo.org/conference2002-fatimah.html

IFLA/UNESCO School Library Manifesto: The School Library in Teaching and Learning for All. 2000. International Federation of Library Associations and Institutions. Available at: http://www. ifla.org/VII/ s1l/ pubs/manifest.htm

Kasbon. (2001). The Electronic Resource Centre (ERC): a Malaysian experiment (Unpublished). Kuala Lumpur: Educational Technology Division, Ministry of Education, Malaysia

Khalid, M. (1997). The best library software for developing countries: more than 30 plus points of Micro CDS/ISIS. Library Software Review 16 no. 1: 12-16.

Malaysia. Ministry of Education. (2003). Educational statistics 2002. Available at: http://www. moe.gov.my/statistik/frinstat.htm.

Malaysia. Ministry of Education.( 2003). Senarai nama sekolah menengah seluruh Malaysia tahun 2002. Kuala Lumpur: Ministry of Education.

Malaysia Ministry of Education. Education Technology Division. (unpublished) Laporan pengautomasian pusat sumber sekolah (PSS) tahun (2001). Kuala Lumpur: Bahagian Teknologi Pendidikan, Kementerian Pendidikan Malaysia.

Meckler, E. M. (2001). The degree and nature to which public school libraries are automated: a survey of public school libraries in Ohio. ED459864

Mohammed Z. (1991) The automation of Academic and Special Libraries in Nigeria: the state of Art inter. lib Rev. 23.

Nancy, A. (2005). "The human resource factor in the Development of appropriate information literacy skills of the Nigerian school child. The role of teacher librarians". A paper presented at $20^{\text {th }}$ Annual conference of NSLA, Kano.

Raw Materials Research and Development Council (RMRDC 2000). X-LIB Library Automation System Manual : Abuja.

Singh, Diljit. 1996. School libraries as catalysts of change. Paper presented at the $10^{\text {th }}$ Congress of Southeast Asian Librarians, Kuala Lumpur, 21-25 May 1996. Kuala Lumpur: CONSAL

Softlink Pty Ltd (1999). Alice for windows Manual Australia

Umar, I. (2007). "Library Automation". A paper presented at Library and Information Science Department A.B.U. Zaria.

Zainab, A.N. and Abrizah, A. (2002). Online library systems for Malaysian school libraries: an experimental approach. In: Singh, D et al (Eds) School libraries for a knowledge society. Paper presented at $31^{\text {st. }}$ IASL Annual Conference and $6^{\text {th }}$ International Forum on research in school librarianship, 5-9 August, at Petaling J aya, Malaysia. 